\title{
X: 9897925-9900718
}

National Cancer Institute

\section{Source}

National Cancer Institute. X: 9897925-9900718. NCI Thesaurus. Code C42005.

Physical location of CSF2RA_Gene 